\title{
SPATIAL VARIABILITY OF LEAF NUTRIENT CONTENTS IN A DRIP IRRIGATED CITRUS ORCHARD
}

\author{
ROBSON A. ARMINDO ${ }^{1}$, RUBENS D. COELHO ${ }^{2}$, MARCONI B. TEIXEIRA ${ }^{3}$, \\ PAULO J. RIBEIRO JUNIOR ${ }^{4}$
}

\begin{abstract}
This study aimed to evaluate the spatial variability of leaf content of macro and micronutrients. The citrus plants orchard with 5 years of age, planted at regular intervals of $8 \times 7 \mathrm{~m}$, was managed under drip irrigation. Leaf samples were collected from each plant to be analyzed in the laboratory. Data were analyzed using the software R, version 2.5.1 Copyright (C) 2007, along with geostatistics package GeoR. All contents of macro and micronutrients studied were adjusted to normal distribution and showed spatial dependence.The best-fit models, based on the likelihood, for the macro and micronutrients were the spherical and matern. It is suggest for the macronutrients nitrogen, phosphorus, potassium, calcium, magnesium and sulfur the minimum distances between samples of 37; 58; 29; 63; 46 and $15 \mathrm{~m}$ respectively, while for the micronutrients boron, copper, iron, manganese and zinc, the distances suggests are 29; $9 ; 113 ; 35$ and $14 \mathrm{~m}$, respectively.
\end{abstract}

KEYWORDS: Citrus latifolia Tan., macronutrients, micronutrients, geostatistics.

\section{VARIABILIDADE ESPACIAL DOS TEORES FOLIARES DE NUTRIENTES EM UM POMAR DE CITROS SOB IRRIGAÇÃO LOCALIZADA}

RESUMO: O objetivo do presente trabalho foi estudar a variabilidade espacial de macro e micronutrientes foliares. O pomar com plantas de 5 anos de idade, plantado com espaçamento regular de $8 \times 7 \mathrm{~m}$, foi manejado sob irrigação localizada. Foram coletadas amostras foliares de cada planta do pomar para serem analisadas em laboratório. Os dados foram analisados por meio do programa computacional R, versão 2.5.1 Copyright (C) 2007, juntamente com o pacote GeoR. Todos os teores de macro e micronutrientes estudados ajustaram-se à distribuição normal e apresentaram dependência espacial. Os modelos de melhor ajuste, com base na verosimilhança, para os macro e micronutrientes, foram esférico e matern. Para os macronutrientes nitrogênio, fósforo, potássio, cálcio, magnésio e enxofre, sugerem-se distâncias mínimas entre amostras de 37; 58; 29; 63; 46 e $15 \mathrm{~m}$, respectivamente, enquanto para os micronutrientes boro, cobre, ferro, manganês e zinco, essas distâncias são de 29; 9; 113; 35 e 14 m, respectivamente.

PALAVRAS-CHAVE: Citrus latifolia Tan., macronutrientes, micronutrientes, geoestatística.

\footnotetext{
${ }^{1}$ Eng ${ }^{\mathrm{o}}$ Agrícola, Prof. Adjunto, Departamento de Solos e Engenharia Agrícola - Setor de Ciências Agrárias, Universidade Federal do Paraná, rarmindo@ufpr.br.

${ }^{2}$ Eng ${ }^{\circ}$ Agrônomo, Prof. Livre Docente, Departamento de Engenharia de Biossistemas, LEB - ESALQ/USP, rdcoelho@esalq.usp.br.

${ }^{3}$ Eng ${ }^{0}$ Agrônomo, Prof. Dr., Instituto Federal Goiano, Câmpus de Rio Verde, marconibt@ gmail.com.

${ }^{4}$ Eng ${ }^{\mathrm{O}}$ Agrônomo, Prof. Associado, Departamento de Estatística, Centro Politécnico da Universidade Federal do Paraná, paulojus@ufpr.br.

Recebido pelo Conselho Editorial em: 28-10-2009

Aprovado pelo Conselho Editorial em: 9-1-2012
} 


\section{INTRODUCTION}

The obtaining of information about the spatial variability of soil and plant properties is of great importance for the assessment of fertility; soil removal, mapping and classification; development of more adequate sampling schemes, aiming to improve the management conditions and increase in crop productivity (CAMPOS et al., 2009).

Before performing a grid of sampling, we should analyze, by means of more sophisticated, statistics, the potential dependence of the variables, the object of study, which are determined by analyzing the samples, i.e., to know whether these variables are dependent or independent one from the other (BARBIERI et al., 2008).

Some technological advances in agriculture and farming have contributed in the technique of sampling points in the area, regular or irregular grid, in order to determine the spatial and temporal variation of properties that affect crop yields by maps of variability. Thereafter, corrective solutions based on these maps have been used, in order to optimize the utilization of resources and to reduce production costs (MOLIN \& MASCARIN, 2007).

Geostatistics was used by FARIAS et al. (2003) to evaluate the spatial variability of yield and fruit size in orange orchards with and without irrigation, in the municipality of Luiz Antônio, state of São Paulo, and concluded that geostatistics has proved to be an extremely useful tool to characterize the variability, to map and to analyze the risk areas, and to assist in program of Precision Agriculture for citrus culture.

Thus, through the use of geostatistics, this study aimed to analyze a set of spatially referenced content in leaves, trying to describe the spatial dependence of the macronutrients and micronutrients in citrus plants, as support for a rational management of fertilization and experimentation in the studied area.

\section{MATERIAL AND METHODS}

This study was conducted at the Experimental Area of Irrigation (Areão Farm) of the Department of Biosystems Engineering, Luiz de Queiroz College of Agriculture, University of São Paulo. The geographic coordinates of the experimental area are: $22^{\circ} 42^{\prime} 30^{\prime \prime}$ South latitude and 47³0'00" West longitude, being at $576 \mathrm{~m}$ above sea level. The climate, according to Köeppen classification, is Cwa type, with mean values of annual rainfall of $1,253 \mathrm{~mm}$, mean annual temperature of $21.2{ }^{\circ} \mathrm{C}$, relative humidity of $74 \%$ wind speed: $2.2 \mathrm{~m} \mathrm{~s}^{-1}$ with predominant direction E/SE. The driest period of the year focuses on the months of June, July and August. The soil of the experimental area was classified as Ultisoil (Red Alfisol). The total study area was $5,975 \mathrm{~m}^{2}$, with a slope of $8.5 \%$.

The studies were conducted in an orchard of 'Tahiti' accid lime (Citrus latifolia Tan.) grafted in 'Rangpur' lime (Citrus limonia Osbeck), aged five years, using 112 plants, doing the liming and fertilization according to RAIJ et al. (1997). The cultural treatments consisted of spraying with chemical pesticides.

Irrigation was scheduled for everyday applications, using an electronic controller and hydraulic valves. On days with precipitation greater than $10 \mathrm{~mm}$, irrigation was cancelled. Irrigation aimed the replacement of crop evapotranspiration (ETc) obtained with a weighing lysimeter located in the center of the area, $4 \mathrm{~m}$ diameter and $1.3 \mathrm{~m}$ deep, consisting of three electronic load cell coupled to an automated collection data (Model CR 23x Campbell Scientific, Logan, UT, USA).

The experiment consisted of seven rows of plants spaced $8 \times 7 \mathrm{~m}$ from each other. However, two rows had a spacing of $9 \times 7 \mathrm{~m}$ according to existence of a terrace (Figure 1). 


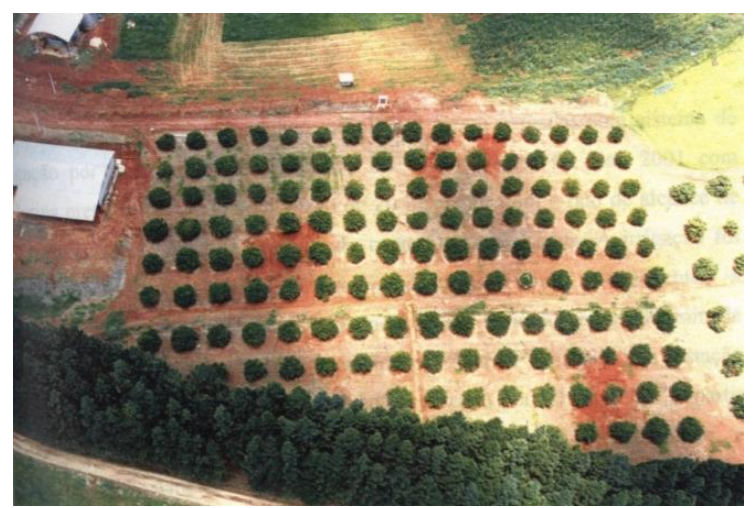

FIGURE 1. Aerial photo of the "Tahiti" acid lime orchard installed at the experimental Areão Farm - ESALQ/USP.

For leaf analysis, it was collected the third pair of leaves of the branch from the fruit in the middle third of canopy of the selected plants, according to the methodology cited by MALAVOLTA (2006) (Figure 2).
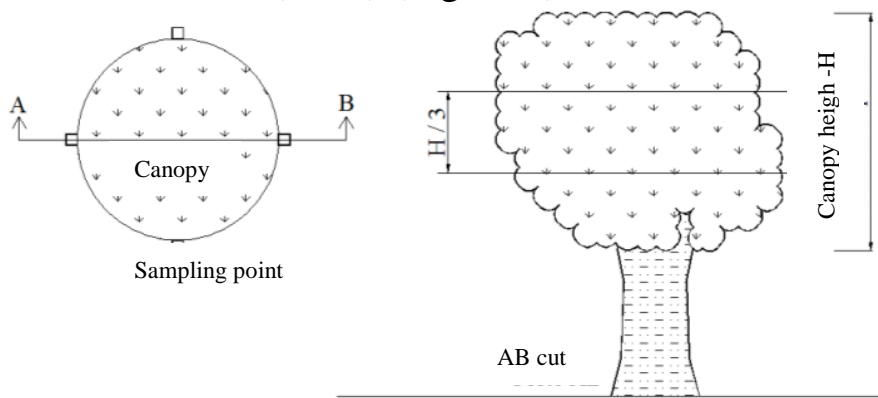

A

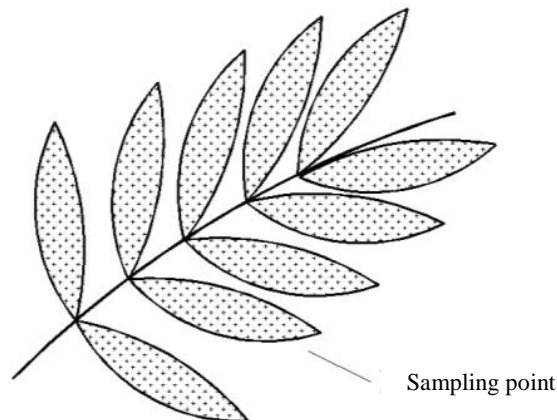

B

FIGURE 2. Representation of the plant sampling points: (a) superior and frontal view and (b) branch.

The nutrient content in leaves were determined in this way: the total nitrogen of the samples were determined by micro Kjeldahl method, according to the methodology cited by MALAVOLTA (2006). In the extract, obtained by nitropercloric digestion, were measured the levels of total $\mathrm{P}$ by colorimetry; the $\mathrm{Ca}, \mathrm{Mg}, \mathrm{Cu}, \mathrm{Fe}, \mathrm{Mn}$ and $\mathrm{Zn}$ contents were measured by atomic absorption spectrophotometry; the contents of $\mathrm{K}$, by flame photometry, the ones of $\mathrm{S}$ by turbidimetry and $\mathrm{B}$ content was extracted by incineration and determined by colometria curmumina.

It was calculated the descriptive statistics of the data by evaluating the frequency distribution of each nutrient contents studied. Moreover, there was an exploratory analysis of the dataset evaluating its possible influence on generated semivariograms and adjusted models. With this analysis, it was possible to understand the structure change of each macro and micronutrients in space. Thus, the characterization of spatial variability allowed the estimation of non-sampled locations, enabling the mapping of the variable.

To verify the normality of the data, it was analyzed the position measurements and the variability of the sets through graphical analysis of the Henry lines. Thus, it was verified the appropriateness of the measures in the face of peripheral value problems, candidates for abnormal values. Soon after, it was ordered the set of data evaluating the symmetry of the distribution of peripheral data. Subsequently, it was sought to confirm or not the validity of these position or dispersion measures, which was done by using some of the techniques of exploratory data analysis, together with a description of the sets of spatial variables obtained (GOMES et al. 2007).

The spatial dependence between observations was identified by the semivariogram estimated by the following equation: 


$$
\gamma^{*}(h)=\frac{1}{2 N(h)} \sum_{i=1}^{N(h)}\left[z\left(s_{i}\right)-z\left(s_{i}+h\right)\right]^{2}
$$

In which,

$$
\begin{aligned}
& \gamma^{*}(h) \text { - semivariance; } \\
& N(h) \text { - number of experimental pairs; } \\
& z\left(s_{i}\right) \text { e } z\left(s_{i}+h\right) \text { - observations, and } \\
& h \text { - distance. }
\end{aligned}
$$

It was used the geoR package of the computer program $\mathrm{R}$ for all values of sample size, mean, median, minimum, maximum, variance, coefficient of variation, the lower quartile and upper quartile. It was adopted the criteria established by WARRICK \& NIELSEN (1980) to classify the elements according to the coefficient of variation. After this analysis, geostatistical analysis was performed adjusting semivariogram values that determine the nugget effect, sill and range. The semivariogram models were selected based on maximum likelihood, and this is calculated by means of a function of the software used. It was tested the following semivariogram models: (a) spherical, $\gamma^{*}(\mathrm{~h})=\mathrm{C} 0+\mathrm{C} 1\left[1.5(\mathrm{~h} / \mathrm{a})-0.5(\mathrm{~h} / \mathrm{a})^{3}\right]$ for $0<\mathrm{h}<\mathrm{a}$ and $\gamma^{*}(\mathrm{~h})=\mathrm{C} 0+\mathrm{C} 1$ for $\mathrm{h}>\mathrm{a}$; (b) exponential, $\gamma$ $*(\mathrm{~h})=\mathrm{C} 0+\mathrm{C} 1[1-\exp (-3 \mathrm{~h} / \mathrm{a})]$ for $0<\mathrm{h}<\mathrm{d}$, in which $\mathrm{d}$ is the maximum distance in which the semivariogram is defined; (c) gaussian, $\mathrm{g}^{*}(\mathrm{~h})=\mathrm{C} 0+\mathrm{C} 1\left[1-\exp \left(-3 \mathrm{~h}^{2} / \mathrm{a}^{2}\right)\right]$ for $0<\mathrm{h}<\mathrm{d}$; (d) matern $\rho$ $(\mathrm{u} ; \phi$, kappa $)=\left[2^{\wedge}(\mathrm{kappa}-1) \gamma(\mathrm{kappa})\right]^{\wedge}(-1)(\mathrm{u} / \phi)^{\wedge}$ kappa $\mathrm{K} \_\kappa(\mathrm{u} / \phi)$, in which $\phi$ and kappa are parameters and $K \_\kappa(\ldots)$ denotes the modified Bessel function of the third order type kappa for $\phi>$ 0 and kappa $>0$.

With the package geoR kriging, spatial variability maps were generated by kriging technique. The ratio between the nugget effect and sill $[\mathrm{CO} /(\mathrm{C} 0+\mathrm{C} 1)]$ might, according to TRANGMAR et al. (1985), classify and compare the analysed macro and micronutrients. The spatial dependence classes have been defined using the classification proposed by CAMBARDELLA et al. (1994) in: strong spatial dependence, for the ratio less than or equal to 0.25 ; moderate spatial dependence, for the ratio greater than 0.25 and less than or equal to 0.75 ; and weak dependence, for the ratio greater than 0.75 .

\section{RESULTS AND DISCUSSION}

As a first step of statistical analysis, it was performed the measurements of position and dispersion for the data sets of macro and micronutrients to citrus plants obtained from leaf analysis (Table 1).

TABLE 1. Descriptive statistics for the original data of macronutrients $\left(\mathrm{g} \mathrm{kg}^{-1}\right)$ and micronutrients $\left(\mathrm{mg} \mathrm{kg}^{-1}\right)$ from leaf analysis.

\begin{tabular}{cccccccccccc}
\hline Statistics & $\mathrm{N}$ & $\mathrm{P}^{*}$ & $\mathrm{~K}$ & $\mathrm{Ca}$ & $\mathrm{Mg}$ & $\mathrm{S}$ & $\mathrm{B}^{*}$ & $\mathrm{Zn}^{*}$ & $\mathrm{Mn}^{*}$ & $\mathrm{Fe}^{*}$ & $\mathrm{Cu}$ \\
\hline Number & 112 & 92 & 112 & 112 & 112 & 112 & 106 & 105 & 103 & 108 & 112 \\
Mean & 20.95 & 1.71 & 12.34 & 9.80 & 3.20 & 2.61 & 88.01 & 14.41 & 22.45 & 169.2 & 7.26 \\
Medium & 20.85 & 1.70 & 12.60 & 9.70 & 3.20 & 2.55 & 87.00 & 15.00 & 21.00 & 160.5 & 7.00 \\
Minimum & 16.40 & 1.40 & 6.40 & 6.99 & 1.90 & 1.50 & 57.00 & 7.00 & 12.00 & 106 & 3.00 \\
Maximum & 25.20 & 2.10 & 18.70 & 12.56 & 5.00 & 4.00 & 129.0 & 22.00 & 37.00 & 265 & 20.00 \\
Variance & 4.06 & 0.03 & 5.70 & 1.35 & 0.31 & 0.25 & 257.63 & 11.47 & 27.84 & 1596 & 11.44 \\
C.V. (\%) & 9.62 & 10.52 & 19.34 & 11.86 & 17.40 & 19.16 & 18.23 & 23.51 & 23.50 & 23.61 & 46.59 \\
Lower quartile & 19.78 & 1.60 & 11.05 & 9.01 & 2.90 & 2.30 & 78.00 & 13.00 & 19.00 & 141 & 5.00 \\
Upper quartile & 22.50 & 1.80 & 13.83 & 10.65 & 3.50 & 2.90 & 98.75 & 17.00 & 26.00 & 195 & 8.00 \\
Assimetry & -0.11 & 0.57 & -0.25 & 0.36 & 0.00 & 0.29 & 0.28 & -0.28 & 0.64 & -0.52 & 0.16 \\
Kurtosis & -0.05 & -0.44 & -0.51 & -0.54 & -0.22 & -0.04 & -0.31 & -0.05 & -0.04 & 0.56 & -0.24 \\
\hline
\end{tabular}

*Data without outliers 
For those nutrients which have had their nutrients and their distribution coefficients of asymmetry and kurtosis affected by outliers, there was a transformation of the data set through the parameter 1 of the function boxcox of geoR package. Table 2 provides a comparative analysis of the obtained values for macronutrients $\left(\mathrm{g} \mathrm{kg}^{-1}\right)$ and micronutrients $\left(\mathrm{mg} \mathrm{kg}^{-1}\right)$ in relation to appropriate levels of macronutrients and micronutrients in leaves indicated by MALAVOLTA (2006).

TABLE 2. Comparative analysis between the average levels of macronutrients $\left(\mathrm{g} \mathrm{kg}^{-1}\right)$ and micronutrients $\left(\mathrm{mg} \mathrm{kg}^{-1}\right)$ obtained in the experiment with appropriate levels.

\begin{tabular}{|c|c|c|c|c|c|c|c|c|c|c|c|}
\hline \multirow{3}{*}{ Mean } & $\mathrm{N}$ & $\mathrm{P}$ & $\mathrm{K}$ & $\mathrm{Ca}$ & $\mathrm{Mg}$ & $S$ & $\mathrm{~B}$ & $\mathrm{Zn}$ & $\mathrm{Mn}$ & $\mathrm{Fe}$ & $\mathrm{Cu}$ \\
\hline & \multicolumn{6}{|c|}{$\mathrm{g} \mathrm{kg}^{-1}$} & \multicolumn{5}{|c|}{$\mathrm{mg} \mathrm{kg}^{-1}$} \\
\hline & 20.95 & 1.71 & 12.34 & 9.80 & 3.20 & 2.61 & 88.01 & 14.41 & 22.45 & 169.2 & 7.26 \\
\hline NA & $24-26$ & $1.2-1.7$ & $10-14$ & $35-40$ & $2-3$ & $2.0-2.5$ & $60-140$ & $25-50$ & $25-50$ & $130-300$ & $10-30$ \\
\hline $\mathrm{AC}$ & $<$ & $>$ & $=$ & $<$ & $>$ & $>$ & $=$ & $<$ & $<$ & $=$ & $=$ \\
\hline
\end{tabular}

The concentration of $\mathrm{K}, \mathrm{B}, \mathrm{Fe}$ and $\mathrm{Cu}$ in the leaves correspond to normal values for age plants in production according to MALAVOLTA (2006), except for $\mathrm{N}, \mathrm{Ca}, \mathrm{Zn}$ and $\mathrm{Mn}$ which obtained levels below the adequate levels; and $\mathrm{P}, \mathrm{Mg}$ and $\mathrm{S}$ obtained levels above the adequate levels for growing citrus.

The choice of a position measurement, mean or median and characterization of the variability of the level of macro and micronutrients in plants should be performed not only by the statistical summary, but also confirmed by the techniques of exploratory data analysis. Thus, the estimation by kriging showed better results, since the data normality was satisfied as recommended by GOMES et al. (2007).

With the exception of Manganese, no other macronutrient evaluated presented values of asymmetry and kurtosis that would not allow processing of data basing on a normal distribution. Following the criterion of WARRICK \& NIELSEN (1980), also used by MONTANARI et al. (2008), the elements N, P and Ca showed low coefficients of variation, because they remained lower than $12 \%$. However, the element $\mathrm{Cu}$ showed high value of coefficient of variation with an index greater than $24 \%$. The other nutrients, in all other tests, showed coefficient of variation in the range of $12-24 \%$. The semivariograms generated for macronutrients and micronutrients (Figures 3 and 4) helped to evaluate the spatial dependence of the analyzed elements. 

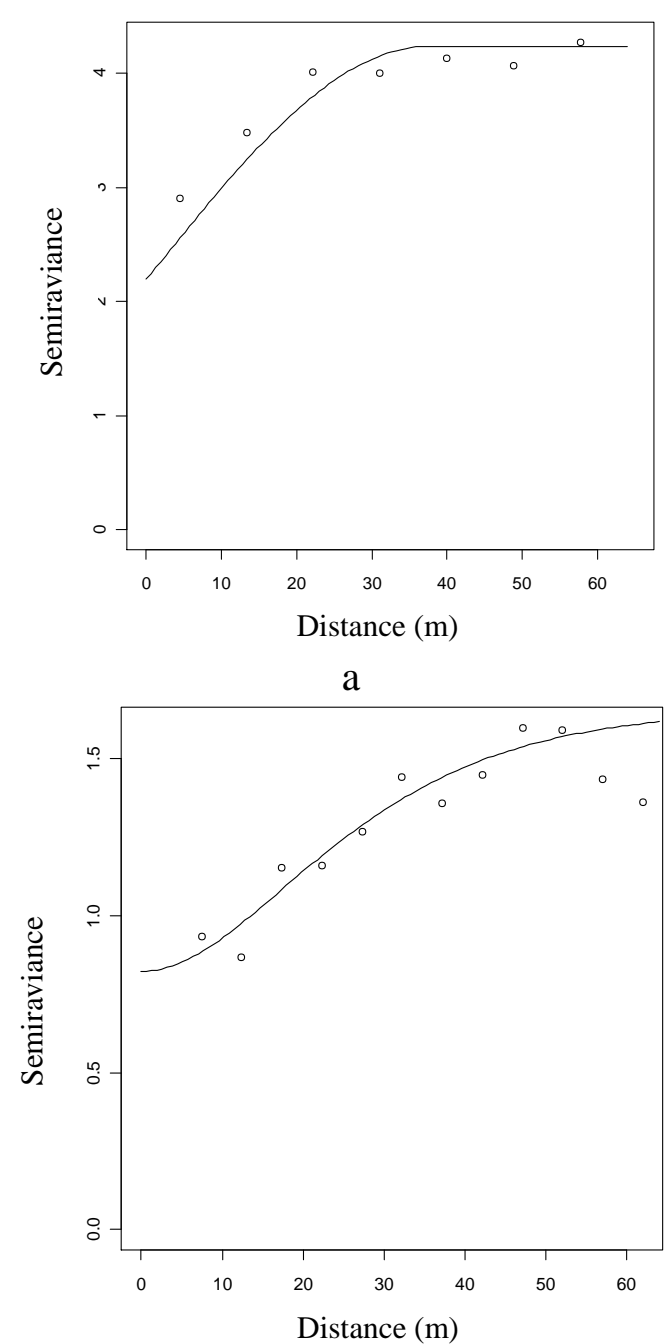

C

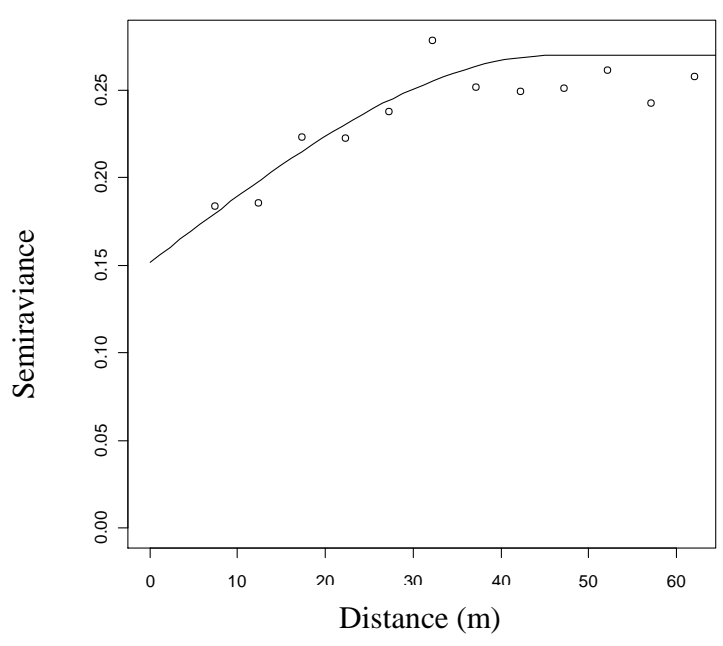

$\mathrm{e}$
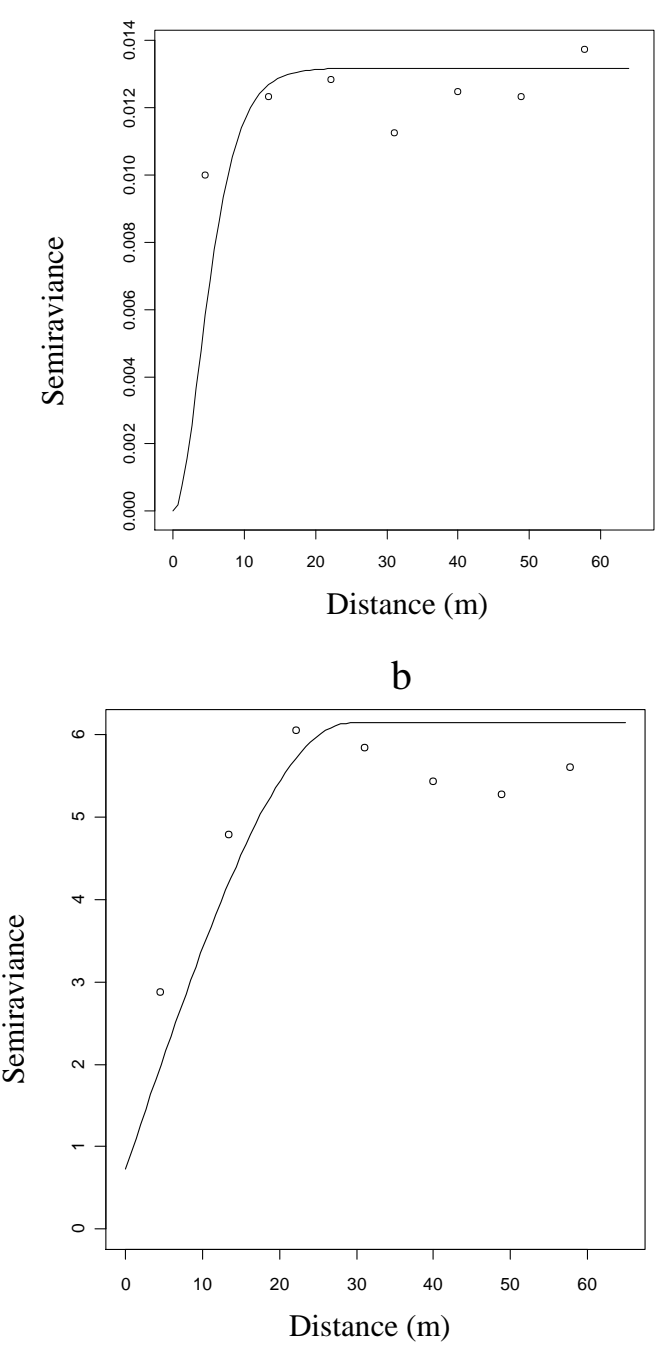

d

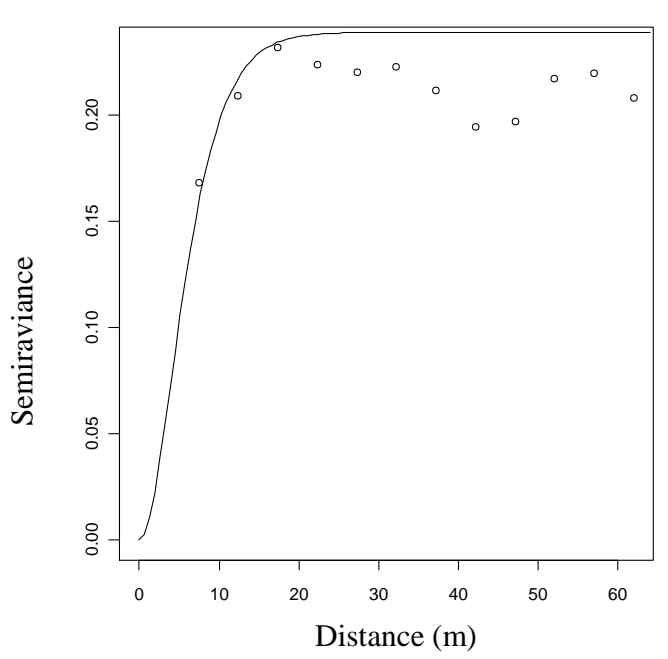

$\mathrm{f}$

FIGURE 3. Experimental semivariograms for the analyzed macronutrients: a) N; b) P; c) Ca; d) K; e) $\mathrm{Mg}$ and $\mathrm{f}) \mathrm{S}$.

The semivariograms of elements $\mathrm{P}, \mathrm{Fe}$ and $\mathrm{Zn}$ may impress the absence of the nugget effect (Figures 3 and 4). However, it is noteworthy that these elements semivariance data were transformed by the conversion coefficient (1) to obtain the best fit models (Table 3). 


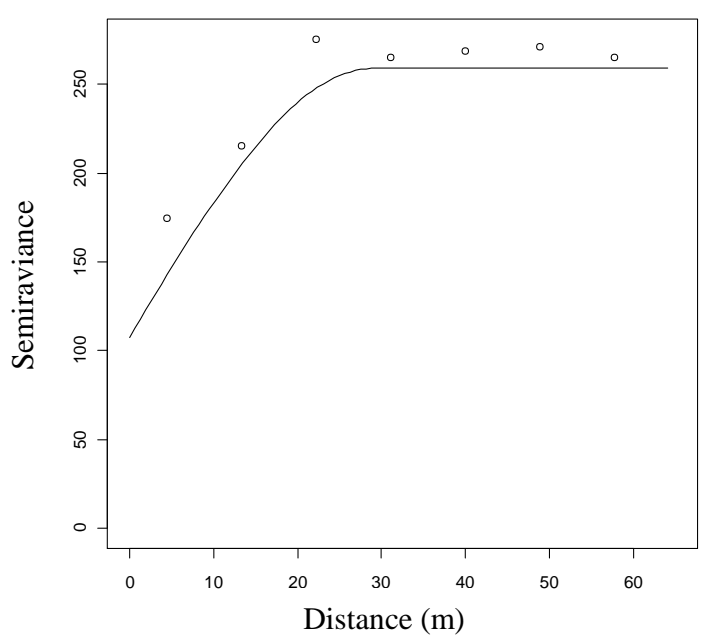

$\mathrm{a}$

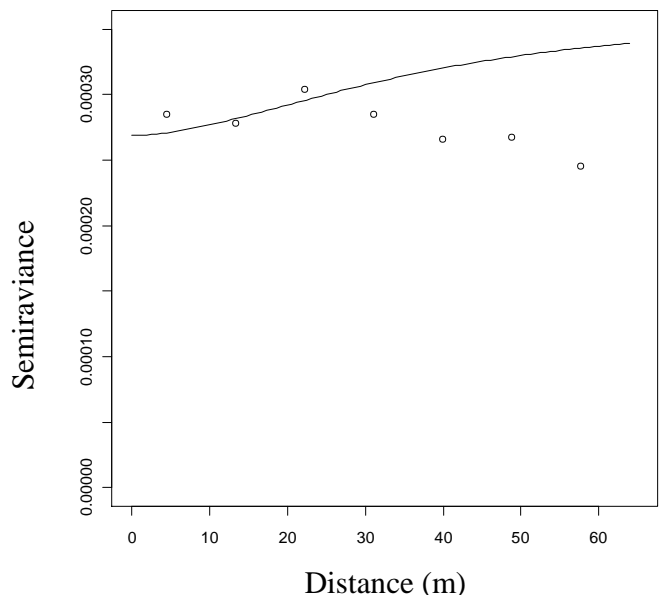

c

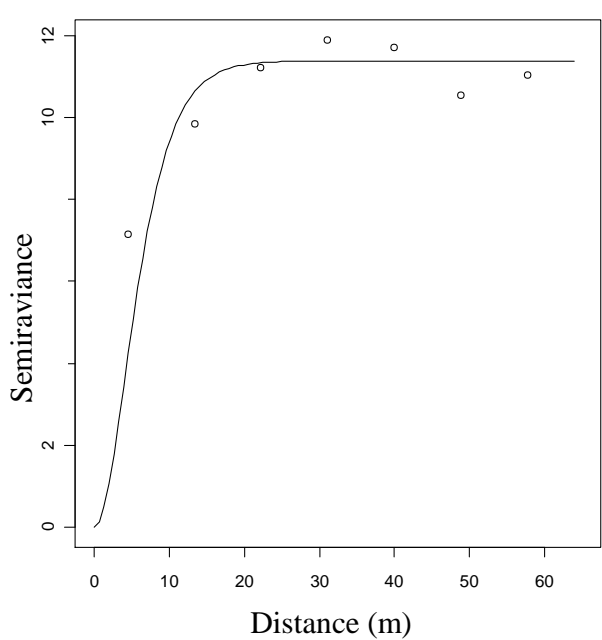

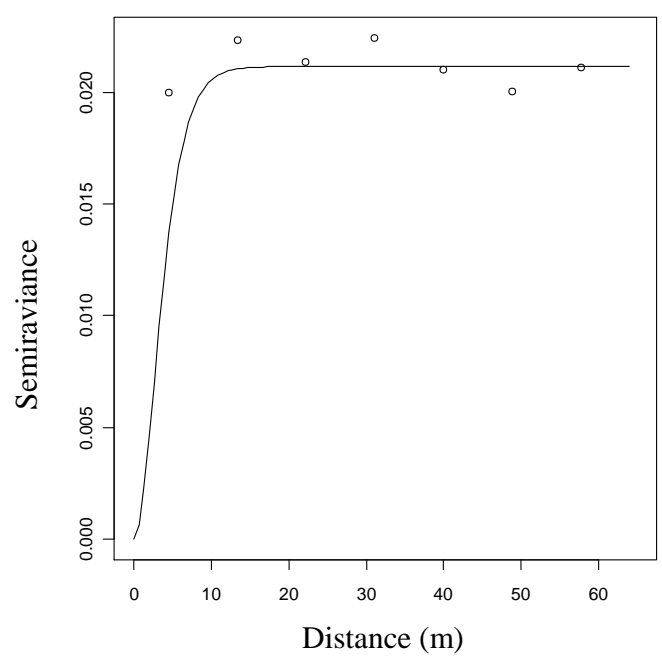

b

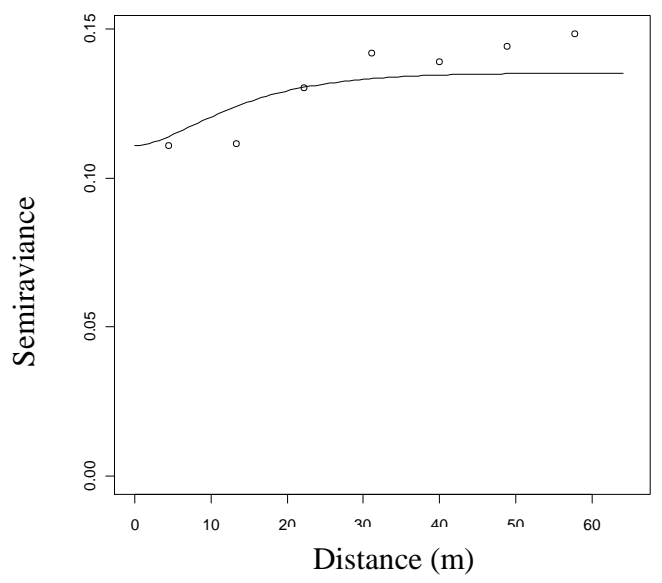

$\mathrm{D}$

e

FIGURE 4. Experimental semivariograms for the analyzed micronutrients: a) B; b) $\mathrm{Cu}$; c) Fe; d) Mn and e) Zn.

Spatial correlation was found by analyzing the semivariograms in all macro and micronutrients (Table 3). All estimated maximum ranges were larger than the adopted spacing between plants, showing the occurrence of spatial dependence for nutrients. The parameters of the adjusted models for macro and micronutrients were used to estimate unsampled locations by kriging technique, thus generating maps to estimate the occurrence of the variables evaluated in the orchard. 
TABLE 3. Model of the experimental semivariograms for the analyzed nutrients

\begin{tabular}{ccccccccc}
\hline Element & Model & $\begin{array}{c}\text { Nugget Effect } \\
\left(\mathrm{C}_{0}\right)\end{array}$ & $\begin{array}{c}\text { Sill } \\
\left(\mathrm{C}_{0}+\mathrm{C}_{1}\right)\end{array}$ & $\begin{array}{c}\text { Range } \\
(\mathrm{a})\end{array}$ & $\mathrm{C}_{0} / \mathrm{C}_{0}+\mathrm{C}$ & Kappa & Likelihood & 1 \\
\hline $\mathrm{N}$ & Esférico & 2.19 & 4.23 & 37.35 & 0.52 & & -226.27 & \\
$\mathrm{P}$ & Matern & 0.003 & 0.004 & 58.37 & 0.71 & 2.50 & 36.13 & -1.00 \\
$\mathrm{~K}$ & Esférico & 0.73 & 6.14 & 29.08 & 0.12 & & -228.30 & \\
$\mathrm{Ca}$ & Matern & 0.82 & 1.66 & 62.59 & 0.50 & 2.50 & -360.80 & 0.50 \\
$\mathrm{Mg}$ & Esférico & 0.21 & 0.32 & 45.85 & 0.65 & & -85.95 & \\
$\mathrm{~S}$ & Matern & 0.00 & 0.25 & 14.92 & 0.00 & 2.50 & -66.65 & \\
$\mathrm{~B}$ & Esférico & 107.75 & 258.91 & 28.91 & 0.42 & & -432.20 & \\
$\mathrm{Cu}$ & Matern & 0.00 & 0.02 & 8.83 & 0.00 & 2.50 & -260.80 & -0.50 \\
$\mathrm{Fe}$ & Matern & 10.53 & 16.59 & 112.64 & 0.63 & 1.50 & -585.20 & 0.50 \\
$\mathrm{Mn}$ & Matern & 0.11 & 0.14 & 35.09 & 0.79 & 1.50 & -311.00 & 0.15 \\
$\mathrm{Zn}$ & Matern & 0.00 & 15.10 & 13.80 & 0.00 & 2.50 & -300.50 & \\
\hline
\end{tabular}

Kappa: adjustment parameter of Matern function; $\lambda$ : data conversion coeficiente (Boxcox).

It was found that the spatial dependence varies from element to element, which was also verified by ZANÃO JÚNIOR, et al. (2010). The elements K, S, Cu and $\mathrm{Zn}$ showed a strong spatial dependence, since the elements $\mathrm{N}, \mathrm{P}, \mathrm{Ca}, \mathrm{Mg}, \mathrm{B}$ and Fe had moderate spatial dependence, whereas Mn was the only element that showed a weak spatial dependence, all classified by CAMBARDELLA et al. (1994).

It was found to the Iron (Fe) micronutrient a high range of about $113 \mathrm{~m}$, which may be explained by the high amount of iron present in the orchard planted on Ultisol, according to studies made by COELHO FILHO et al. (2001). Based on the semivariograms model presented, maps were generated by kriging estimate contour (Figure 5).

The maps of isolines of the macronutrients $\mathrm{N}$ and $\mathrm{P}$ indicate that plants in the orchard assessed presented deficiency of these elements in the center of the area studied, with correlation $(\mathrm{r}=0.51)$ between these elements (Figure 5). The absorption of $\mathrm{P}$ by the plants may be affected by several factors such as the presence of microorganisms in the root system, which can increase the absorption surface of this element, causing variability of absorption by the plants of the same orchard. Since the element $\mathrm{Ca}$ was negatively correlated with $\mathrm{N}(\mathrm{r}=-0.68)$ and also with the $\mathrm{P}$ $(\mathrm{r}=-0.47)$, showing high concentration values in the same central region of the studied area that can be explained by the preference of absorption of plants in this region by this element, lyotropic series (OLIVEIRA et al., 2011). The high spatial variability of $\mathrm{K}$ and $\mathrm{S}$ may be attributed to several factors as: the variability in power extraction plant, the mechanism of contact of nutrients with the root system of citrus, and the possible spatial variability of some soil physical properties, such as the bulk density. The high concentration of Magnesium $(\mathrm{Mg})$ may be explained by the high concentration of clay, since the experimental area is classified as red earth. 

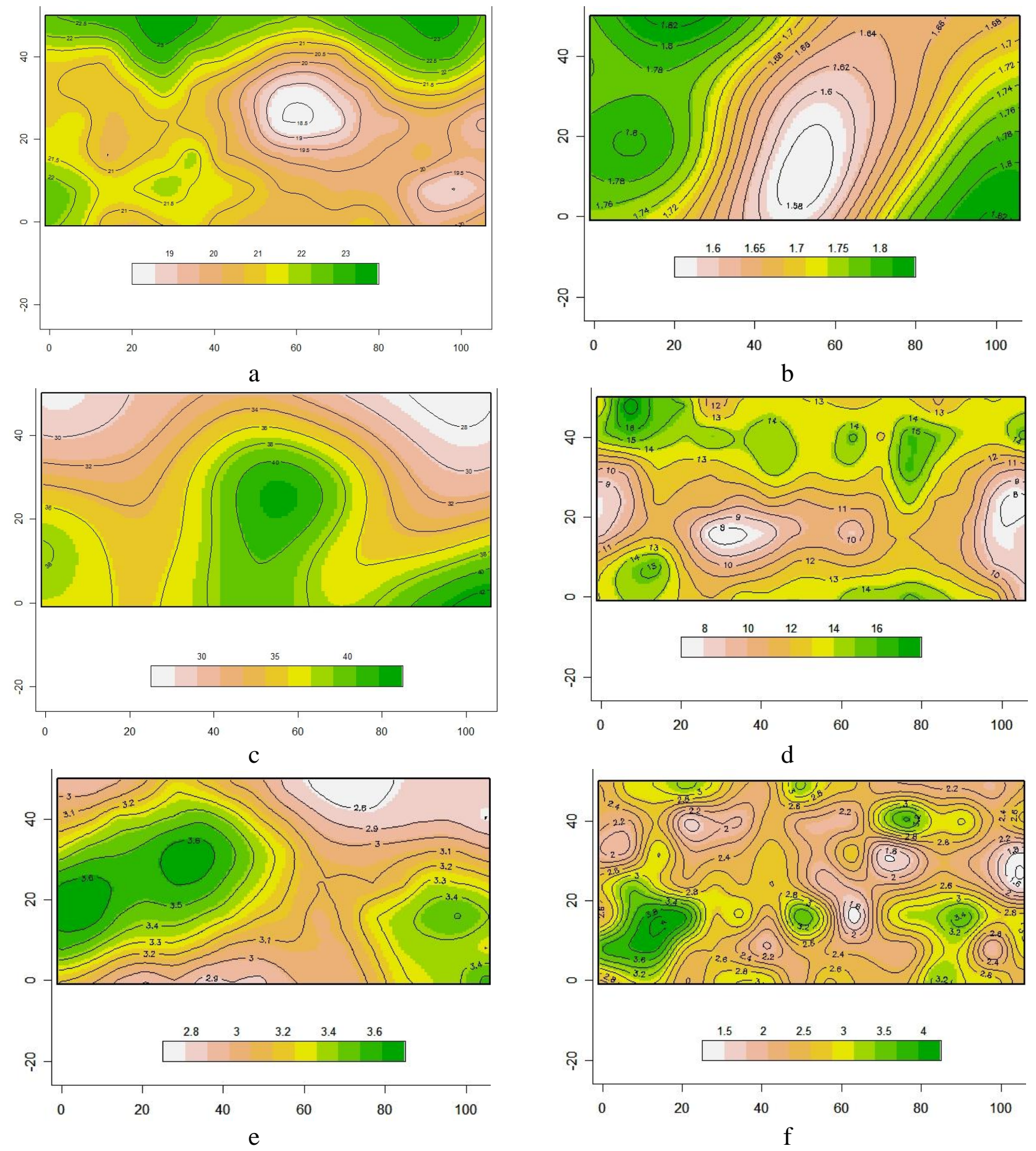

FIGURE 5. Maps of isolines for the macronutrients analyzed: a) N; b) P; c) Ca; d) $\mathrm{K}$; e) $\mathrm{Mg}$; f) $\mathrm{S}$.

The higher concentration of Fe in the bottom of the orchard may be explained by the high concentration of clay at that location, due to a potential carrying of this material provided by the direction of the slope of the soil (Figure 6). The high variability of absorption of other micronutrients, $\mathrm{B}, \mathrm{Cu}, \mathrm{Mn}$ and $\mathrm{Zn}$, by plants may be allocated by the mobility of these elements in the plants and/or soil. It is hoped that the study of variability of leaf composition between plants minimize the sampling effort, without sacrificing representativeness, serving as auxiliary tool in determining a grid to collect information of soil. 

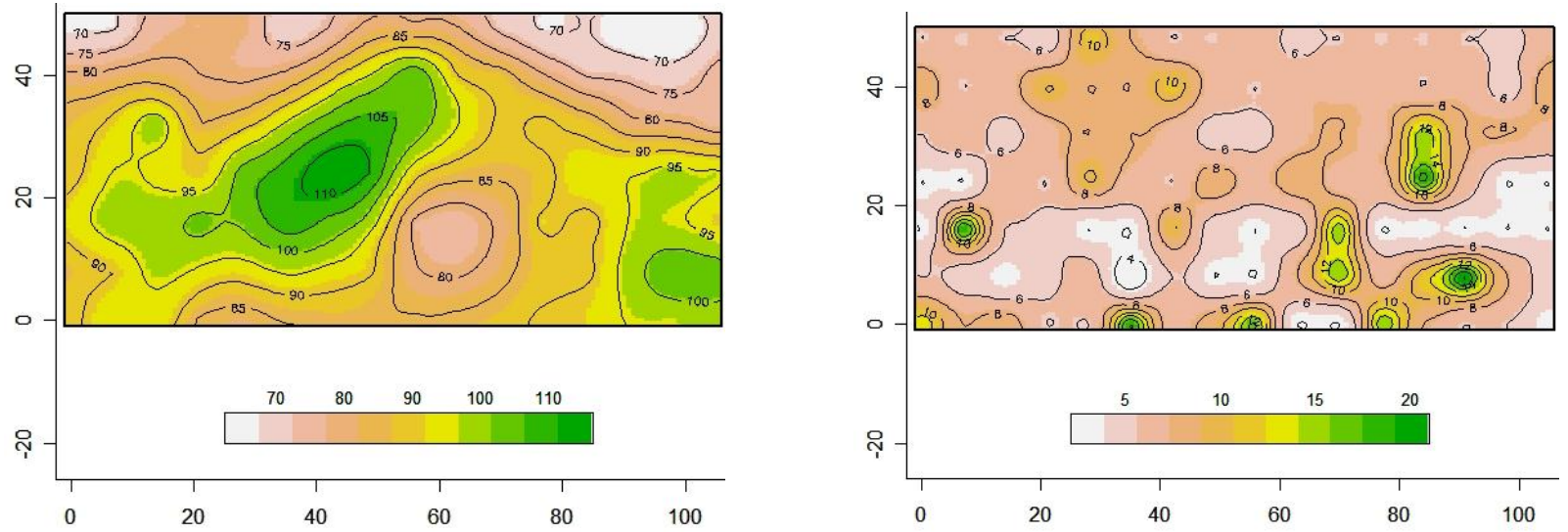

a

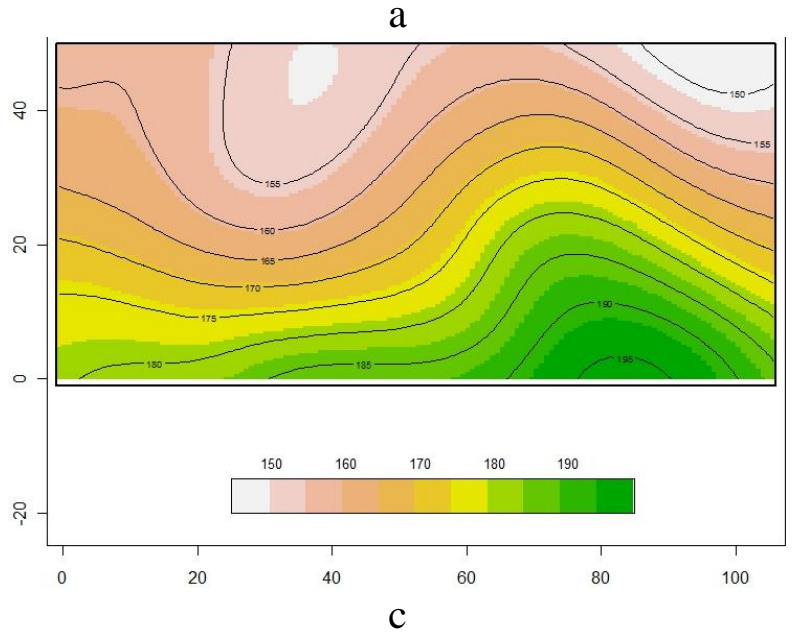

b
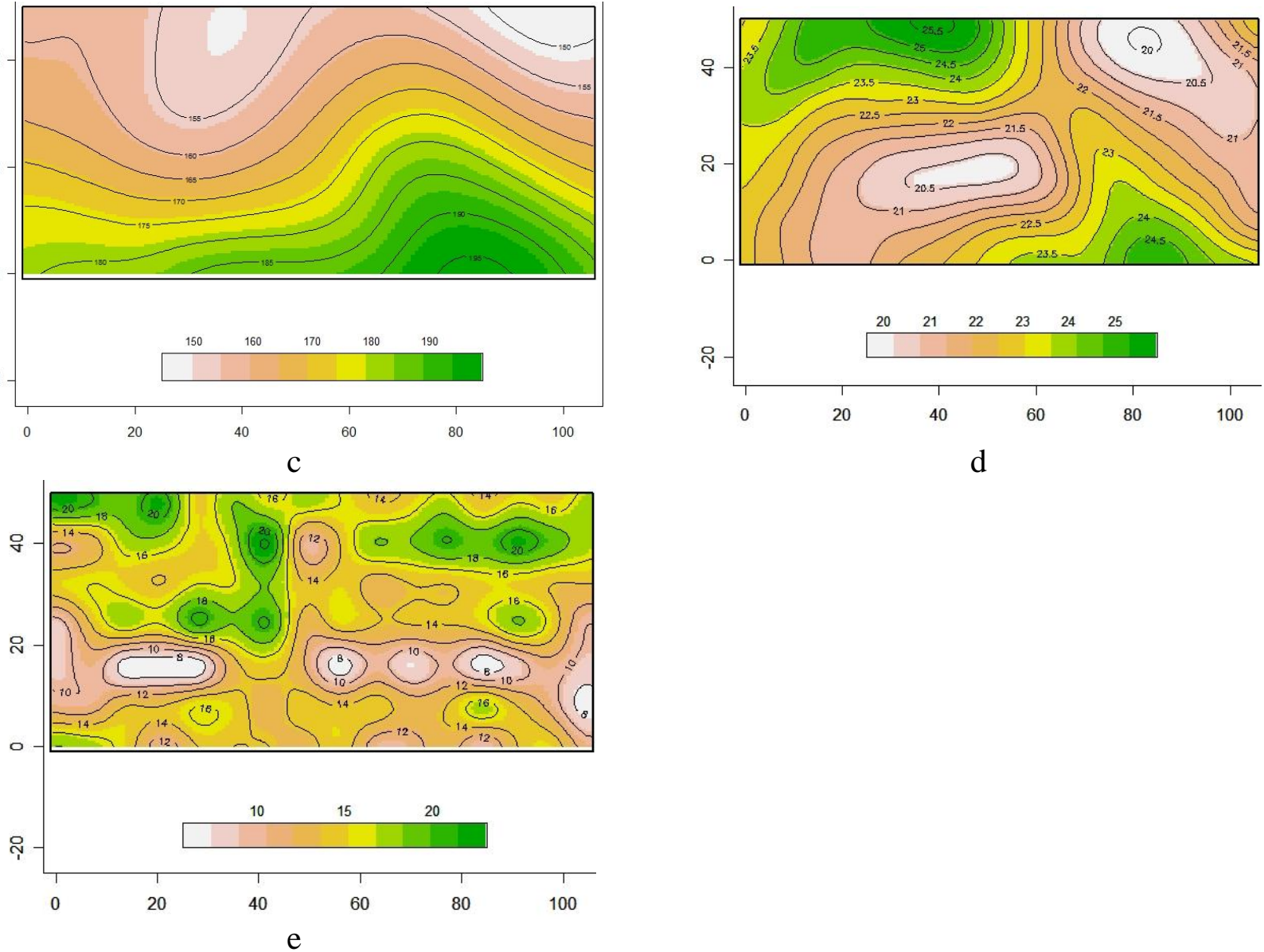

FIGURE 6. Maps of isolines for the micronutrients analyzed: a) B; b) Cu; c) Fe; d) Mn and e) Zn.

\section{CONCLUSIONS}

The coefficient of variation $(\mathrm{CV})$ allowed characterization of the variables $\mathrm{P}, \mathrm{Ca}, \mathrm{Mg}, \mathrm{B}$ and $\mathrm{S}$ as the mean variation, and $\mathrm{Mn}, \mathrm{Zn}, \mathrm{Fe}$ and $\mathrm{Cu}$ as high variation. Nitrogen was characterized as low variation.

All macro and micronutrients showed spatial dependence structure, which allowed its mapping, using geostatistical techniques.

The best models for adjustments, based on the likelihood, for the macro and micronutrients were spherical and Matern.

For the macronutrients, it was suggest the distance between samples of 37, 58, 29, 63, 46 and 15 meters for $\mathrm{N}, \mathrm{P}, \mathrm{K}, \mathrm{Ca}, \mathrm{Mg}$ and $\mathrm{S}$, respectively.

For the micronutrients, it was suggest the distance between samples of 29, 9, 113, 35 and 14 meters for $\mathrm{B}, \mathrm{Fe}, \mathrm{Mn}$ and $\mathrm{Zn}$, respectively. 


\section{ACKNOWLEDGEMENT}

The authors thank the Ministry of Science and Technology (MCT), the National Council for Scientific and Technological Development $(\mathrm{CNPq})$ and Foundation for Research Support of São Paulo (FAPESP), for financially supporting this research through the Nacional Institute of Science and Technology in Irrigation Engineering (INCTEI).

\section{REFERENCES}

BARBIERI, D.M.; MARQUES JUNIOR, J.; PEREIRA, G.T. Variabilidade espacial de atributos químicos de um argissolo para aplicação de insumos à taxa variável em diferentes formas de relevo. Engenharia Agrícola, Jaboticabal, v.28, n.4, p.645-653, 2008.

CAMBARDELLA, C.A.; MOORMAN, T.B.; NOVAK, J.M.; PARKIN, T.B.; TURCO, R.F.; KONOPKA, A.E. Field-scale variability of soil properties in central Iowa soils. Soil Science Society of America Journal, Madison, v.58, n.5, p.1.501-1.511, 1994.

CAMPOS, M.C.C.; MARQUES JÚNIOR, J.; PEREIRA, G.T.; SOUZA, Z.M. de; MONTANARI, R. Planejamento agrícola e implantação de sistema de cultivo de cana-de-açúcar com auxílio de técnicas geoestatísticas. Revista Brasileira de Engenharia Agrícola Ambiental, Campina Grande, v.13, n.3, p.297-304, 2009.

COELHO FILHO, M.A.; COELHO R.D.; GONÇALVES, A.C.A. Variabilidade espacial de variáveis físico-hídricas do solo em um pomar de lima ácida Tahiti, irrigado por microaspersão. Revista Brasileira de Engenharia Agrícola Ambiental, Campina Grande, v.5, n.2, p.239-246, 2001.

FARIAS, P.R.S.; NOCITI, L.A.S.; BARBOSA, J.C.; PERECIN, D. Agricultura de precisão: mapeamento da produtividade em pomares cítricos usando geoestatística. Revista Brasileira de Fruticultura, Jaboticabal, v.25, n.2, p.235-241, 2003.

GOMES, N.M.; SILVA, A.M.; MELLO, C.R.; FARIA, M.A.; OLIVEIRA, P.M. Métodos de ajuste e modelos de semivariograma aplicados ao estudo da variabilidade espacial de atributos físicohídricos do solo. Revista Brasileira de Ciência do Solo, Viçosa, v.31, p.435-443, maio/jun. 2007.

MALAVOLTA, E. Manual de nutrição mineral de plantas. São Paulo: Ceres, 2006. 638 p.

MOLIN, J.P.; MASCARIN, L.S. Colheita de citros e obtenção de dados para mapeamento da produtividade. Engenharia Agrícola, Jaboticabal, v.27, n.1, p. 259-266, 2007.

MONTANARI, R.; PEREIRA, G.T.; MARQUES JÚNIOR, J.; SOUZA, Z.M.; PAZETO, R.J.; CAMARGO, L.A. Variabilidade espacial de atributos químicos em Latossolo e Argissolos. Ciência Rural, Santa Maria, v.38, p.1266-1272, ago/set. 2008.

OLIVEIRA, F.A.; MEDEIROS, J.F.; DUARTE, S.N.; SILVA JÚNIOR, M.J.; CAMPELO, C.H. Calibração de extratores providos de cápsula porosa para monitoramento da salinidade e da concentração de íons. Engenharia Agrícola, Jaboticabal, v.31, n.3, p.520-528, 2011.

RAIJ, B. van; CANTARELLA, H.; QUAGGIO, J.A.; FURLANI, A.M.C. Recomendações deadubação e calagem para o Estado de São Paulo. 2.ed. Campinas: Instituto Agronômico/Fundação IAC, 1997. 285 p. (Boletim Técnico, 100).

TRANGMAR, B.B.; YOST, R.S.; UEHARA, G. Applications of geoestatistics to spatial studies of soil proprieties. Advances in Agronomy, Kent, v.38, p.45-94, 1985.

WARRICK, A.W.; NIELSEN, D.R. Sapatial variability of soil physical properties in the field. In: HILLEL, D. Application of soil physics. New York: Academic Press, 1980. v.1, p.319-344.

ZANÃO JÚNIOR, L.A.; LANA, R.M.Q.; GUIMARÃES, E.C.; PEREIRA, J.M.A. Variabilidade espacial dos teores de macronutrientes em latossolos sob sistema plantio direto. Revista Brasileira de Ciência do Solo, v.34, p.389-400, set/out. 2010. 